\title{
ANALYSIS OF COMMON DIFFICULTIES IN TOEFL READING COMPREHENSION \\ (A Case Study on the Second Semester Students of English Study Program Islamic University of Indragiri)
}

\author{
Maizarah \\ Islamic University of Indragiri-Tembilahan \\ E-mail: maizarah_nurzainal@yahoo.com
}

\begin{abstract}
The problem in this study was the students' common difficulties in TOEFL Reading Comprehension. This study only used one variable. The research method used in this study was descriptive research. The purpose of this study was to know the students' common difficulties in TOEFL Reading Comprehension in the second semester of English Study Program at the Islamic University of Indragiri Tembilahan. The total of the sample used in this study was 23 students, the technique was used to take the sample is total sampling. In collecting the data, the researcher used a test. After the data has been collected, the result of the test showed that the skills that are considered to be the most difficult ones in TOEFL reading, which is skill 3 . This skill is identifying stated detail questions correctly. It is the highest percentage (84\%) with the total of the incorrect answer is 210 from 5 items. Then, it is followed by skill $5(82 \%)$ with the total of the incorrect answer is 82 from 2 items, which is finding pronoun reference. It is the second most difficult skill for the students. The third most difficult skill is skill 7. It is responding of transition question achieve $81 \%$ with the total of incorrect answers is 81 from 2 items. Next, skill 10 is considered to be the fourth most difficult skill in TOEFL reading comprehension. The questions are about the use of context to give the meaning of the difficult word which is counted $80 \%$ from the total of incorrect answers is 120 from 3 items. Then, the fifth most difficult skill in TOEFL reading comprehension is skill 1 , which is consisting the questions about answering main idea questions correctly, students made $78 \%$ of the total incorrect answers is 156 from 4 items.
\end{abstract}

Keywords: Common Difficulties, TOEFL Reading Comprehension

\begin{abstract}
Abstrak
Masalah dalam penelitian ini adalah kesulitan yang sering muncul dalam TOEFL pemahaman bacaan (reading comprehension). Penelitian ini hanya menggunakan 1 variabel. Metode penelitian yang digunakan adalah penelitian deskriptif. Tujuan dari penelitian ini adalah untuk mengetahui kesulitan yang sering muncul dalam TOEFL pemahaman bacaan (reading comprehension) pada siswa semester 2 Program Studi Bahasa Inggris di UNISI Tembilahan. Jumlah sample yang digunakan dalam penelitian ini adalah sebanyak 23 siswa, tehnik pengambilan sampel dalam penelitian ini adalah total sampling. Dalam mengumpulkan data,
\end{abstract}


peneliti menggunakan tes. Setelah data dikumpulkan, hasil menunjukkan bahwa skil yang paling sulit adalah skil 3 yaitu mengidentifikasi pertanyaan detail, dengan persentase (84\%), dengan jumlah jawaban salah adalah 210 dari 5 soal. Selanjutnya adalah skil 5 (82\%) dengan jumlah jawaban salah adalah 82, ini adalah menemukan rujukan kata. Skil tersulit ketiga adalah skil 7 (81\%), yaitu mengenai soal transisi dengan jumlah jawaban salah adalah 81 dari 2 soal. Kemudian, skil 10 adalah soal tersulit keempat yait mengenai penggunaan konteks dalam mencari kata sulit yaitu mencapai $80 \%$ dengan jumlah jawaban salah adalah 120 dari 3 soal. Soal tersulit kelima adalah skil 1, yaitu soal mengenai menjawab ide pokok secara benar, yaitu $78 \%$ dengan total jawaban salah adalah 156 dari 4 soal.

\section{Kata kunci: Kesulitan Umum, TOEFL Pemahaman Membaca}

\section{INTRODUCTION}

English has been recognized as an international language that is more dominantly used in all countries in the world. This language is widely used for many purposes such as in science, technology, politics, education, etc. As stated by Lauder (2008) in Mappiasse (2014:114) that English is being used for technological and scientific purposes and also for better job opportunities. This condition required people to have English proficiency to face the globalization era. In the globalization era that is filled by challenges and competitions are super tight, one of the skills that most needed today is the English language. TOEFL (Test of English as a Foreign Language) is one of the measurements for English proficiency. Phillips (2001: xiii) states that the TOEFL test is a test to measure the level of English proficiency of non-native speakers of English. It is required primarily by English-language colleges and universities. Additionally, institutions such as government agencies, businesses, or scholarship programs may require this test.

As an English proficiency test, TOEFL has a difficulty level. Sujana in Ismalia (2015:2) explains that the TOEFL test has three sections; Listening Comprehension, Structure \& Written Expression, and Reading Comprehension. In Listening Comprehension, timing is about 0.7 minutes for one item. Students must listen to the 
conversation, read the answer, analyze the answer, then choose the answer. In Structure \& Written Expression, timing is only 0,6 minutes for one item. In Reading Comprehension, timing is about 1 minute for one item. In conclusion, to get a high score in the TOEFL test requires the combination of the three.

In many universities TOEFL is one of the graduation requirements including UNISI will be implemented the TOEFL test, the students must prepare themselves to be able to face the TOEFL. To get the high score of TOEFL test for the three sections is not easy including reading comprehension, the difficulty in reading comprehension section experienced by test takers is due to the limited time they have during the test, and lack of knowledge in reading aspects.

\section{Reading Comprehension}

Paris \& Stahl (2005:83) state reading is generally described as involving two skills: decoding and comprehension. Decoding is an isolable ability, which can be taught and assessed in straightforward ways. Comprehension, in contrast, is a complex skill that depends on a variety of factors, contexts, and reading goals. Both learner factors, text factors, as well as instruction, all play a role. For this chapter, we discuss the first two.

Furthermore, Westwood (2008:32) states reading comprehension can be defined as an active thinking process that a reader intentionally constructs meaning to form a deeper understanding of concepts and information presented in a text. To comprehend, readers must use the information they already possess to filter, interpret, organize and reflect upon the incoming information from the page. The efficient interpretation of text involves a combination of word recognition skills, linking of new information to prior knowledge, and application of appropriate strategies such as locating the main idea, making connections, questioning, inferring and predicting. Furthermore, McCardle et al. in Westwood (2008:32) suggest that comprehension processes draw on many cognitive and linguistic 
abilities - most notably, vocabulary, recalling background knowledge, sentence processing, verbal reasoning, knowledge of print conventions and working memory. Weakness in any of these abilities can impair reading comprehension and can cause a student to disengage from the task of interpreting the text.

Moreover, Woolley (2011:15) defines reading comprehension as the process of making meaning from text. The goal, therefore, is to gain an overall understanding of what is described in the text rather than to obtain meaning from isolated words or sentences. Also, Snow (2002: xiii) defines reading as the process of simultaneously extracting and constructing meaning through interaction and involvement with written language. It consists of three elements: the reader, the text, and the activity or purpose for reading.

In conclusion to the discussion above, reading comprehension is the ability to read the text, process it, and understand its meaning. It means when one reads a text they should interpret the meaning of words and find the information from the text.

\section{TOEFL Test}

TOEFL (Test of English as a Foreign Language) is used to measure the students' or ones' English skills. Many educational institutions give the requirement that who want to start or finish in their institution must pass the TOEFL Test. This becomes a benchmark for someone regarding their English skill; the higher value of TOEFL means the better English skill which they have.

Moreover, in this globalization era, TOEFL is already being used in the world of work. Many workplaces have used TOEFL as one of the mechanisms for recruitment or promotion. This is a way to deal with the job competition or to establish cooperation, more advanced one's business allows the wider cooperation to other countries, and then English is used as the connecting language. 
Aspects and Skills in TOEFL

\section{Reading Section}

There are several aspects and skills to comprehend the reading text of the TOEFL test. According to Phillips (2003) in Iskandar Abdul Samad (2017:31), there are five aspects of TOEFL reading comprehension that consist of 13 skills. First, questions are about the ideas of the passage. This aspect consists of two skills: answering main idea questions correctly and recognizing the organization of ideas. Secondly, they directly answered questions. This aspect consists of three skills: answering stated detail questions correctly, finding unstated details, and finding pronoun referents. Thirdly, they indirectly answered questions. This aspect consists of two skills, these are responding to implied and transition questions. The fourth is vocabulary questions which consists of four skills, these are finding out meanings from structural clues, finding word parts, giving meaning for difficult and simple words by using context. Lastly, they review questions. This aspect consists of the ability to search for specific information, the tone, purpose, or course. This study focuses on the most difficult parts of reading aspects faced by students of the second semester of English Study Program at the Islamic University of Indragiri.

\section{METHOD}

This research is descriptive research. Gay (2000:275) stated that "descriptive study determines and describes the way things are. The total population used in this study was 23 students, the technique was used to take the sample is total sampling, so the sample of this study was 23 students of the second semester of English Study Program in the Islamic University of Indragiri Tembilahan. The technique used to collect the data was reading the TOEFL test which consists of 50 questions. The data were analyzed statistically. 
FINDINGS AND DISCUSSION

Result of the Test
The following table presents the result of data from the test is the percentage of each skill.

Table 1. Test Result

\begin{tabular}{|c|c|c|c|c|}
\hline Aspect & Skills & $\begin{array}{c}\text { Total of } \\
\text { Item }\end{array}$ & Total & $\begin{array}{c}\text { Percentage } \\
(\%)\end{array}$ \\
\hline \multirow{2}{*}{ I } & $\begin{array}{l}\text { 1. Answering the main idea } \\
\text { questions correctly. }\end{array}$ & 4 & 156 & 78 \\
\hline & $\begin{array}{l}\text { 2. Recognizing the organization } \\
\text { of Ideas. }\end{array}$ & 3 & 111 & 74 \\
\hline \multirow{3}{*}{ II } & $\begin{array}{l}\text { 3. Answering stated detail } \\
\text { questions correctly. }\end{array}$ & 5 & 210 & 84 \\
\hline & 4. Finding unstated details. & 8 & 284 & 71 \\
\hline & 5. Finding pronoun reference & 2 & 82 & 82 \\
\hline \multirow[t]{2}{*}{ III } & $\begin{array}{l}\text { 6. Responding to implied } \\
\text { questions. }\end{array}$ & 5 & 188 & 75 \\
\hline & $\begin{array}{l}\text { 7. Responding to transition } \\
\text { questions. }\end{array}$ & 2 & 81 & 81 \\
\hline \multirow{4}{*}{ IV } & $\begin{array}{l}\text { 8. Finding out meanings from } \\
\text { structural clues. }\end{array}$ & 3 & 106 & 71 \\
\hline & $\begin{array}{l}\text { 9. Finding out meanings from } \\
\text { word parts. }\end{array}$ & 5 & 192 & 77 \\
\hline & $\begin{array}{l}\text { 10. The use of context to give } \\
\text { the meaning of difficult } \\
\text { words. }\end{array}$ & 3 & 120 & 80 \\
\hline & $\begin{array}{l}\text { 11. The use of context to give } \\
\text { the meaning of simple } \\
\text { words. }\end{array}$ & 4 & 153 & 77 \\
\hline \multirow[t]{2}{*}{$\mathbf{V}$} & $\begin{array}{l}\text { 12. The ability to search for } \\
\text { specific information. }\end{array}$ & 3 & 115 & 77 \\
\hline & $\begin{array}{l}\text { 13. The ability to identify the } \\
\text { tone, purpose, or course. }\end{array}$ & 3 & 114 & 76 \\
\hline \multicolumn{2}{|c|}{ Total Incorrect Answer } & 50 & 1912 & 76 \\
\hline
\end{tabular}

Table 1 above shows the skills that are considered to be the most difficult ones in TOEFL reading, which is skill 3. This skill is identifying stated detail questions correctly. It is the highest percentage $(84 \%)$ with the total of the incorrect answer is 210 from 5 items. Then, it is followed by skill $5(82 \%)$ with the total of the incorrect answer is 82 from 2 items, which is finding pronoun reference. It is the second most difficult skill for the students. The third most difficult skill is skill 
7. It is responding of transition question achieve $81 \%$ with the total of incorrect answers is 81 from 2 items. Next, skill 10 is considered to be the fourth most difficult skill in TOEFL reading comprehension. The questions are about the use of context to give the meaning of the difficult word which is counted 80 $\%$ from the total of incorrect answers is 120 from 3 items. Then, the fifth most difficult skill in TOEFL reading comprehension is skill 1, which is consisting the questions about answering main idea questions correctly, students made $78 \%$ of the total incorrect answers is 156 from 4 items.

\section{Discussion}

The purpose of this study was to know the students' common difficulties in TOEFL Reading Comprehension in the second semester of English Study Program at the Islamic University of Indragiri Tembilahan. In this research the researcher gave a test to collect the data of students' common difficulties in TOEFL Reading Comprehension, the resulting test show that there are five difficulties as the most difficulties in TOEFL Reading Comprehension; 1) identifying stated detail questions correctly, 2) finding pronoun reference, 3) responding of transition question, 4) about the use of context to give meaning of difficult word, 5) answering main idea questions correctly.

As a result, the students have the difficulty in TOEFL reading comprehension, It needs a serious way and effort to overcome and decrease their difficulties by themselves.

\section{CONCLUSION}

Based on the finding and discussion, it could be concluded that student has a big problem on Reading TOEFL Comprehension; it was known from the result of the test that the incorrect answer is bigger than the correct answer. So, the studentts mustpractice more to read and answer an English text especially the texts are related to the TOEFL Reading section. 


\section{REFERENCES}

Gay, L.R and Airasian, Peter. (2000). Educational research. Saddle River: New Jersey.

Mappiasse, Sitti Syamsinar. 2014. Evaluation of English as a Foreign Language and its Curriculums in Indonesia. University Teknologi Malaysia: Malaysia.

Paris, Scoot G \& Stahl, Steven A. 2005. Children's Reading Comprehension and Assessment. Lawrence Erlbaum Associates, Inc., Publishers.

Philips, Deborah, 2001, Longman Complete Course for the TOEFL Test, A Pearson Education Company.

Samad, Iskandar Abdul, et.al, EFL Students' Strategies dealing with common difficulties in TOEFL Reading Comprehension Section, International Journal of Education, Vol 1 No1, March 2017, p,29-36

Snow, Katherine. 2002. Reading for Understanding toward an $R \& D$ Program in Reading Comprehension. RAND.

WestWood, Peter. 2008. What Teachers Need to Know About: Reading and Writing Difficulties. Acer Press: Australia.
Woolley, G. 2011. Reading Comprehension: Assisting Children with Learning Difficulties, DOI 10.1007/978-94-007-11747_2, Springer Science + Business Media B.V. 